\title{
The Effect of Search, Solve, Create and Share Learning Models to Improve Students 'Critical Thinking Skills on Acid and Basic Titration Materials
}

\author{
Siti Nur Arisa ${ }^{1}$ Ibnu Khaldun² ${ }^{*}$, Safrida ${ }^{3}$ \\ ${ }^{1}$ Science Education Study Program, Postgraduate Program, Syiah Kuala University, Banda Aceh, Indonesia \\ ${ }^{2}$ Chemistry Study Program, FKIP, Syiah Kuala University, Banda Aceh, Indonesia \\ ${ }^{3}$ Biology Study Program, FKIP, Syiah Kuala University, Banda Aceh, Indonesia
}

DOI: $\underline{10.29303 / \text { ippipa.v7i2.625 }}$

\section{Article Info}

Received : February 9th, 2021

Revised : April 3th, 2021

Accepted: April 7th, 2021

\begin{abstract}
This study aims to determine the improvement of students 'critical thinking skills in the acid-base titration material and to know the description of students' responses to learning to search, solve, create, and share. This study used an experimental method, comparing the experimental group with the control group through the pretest-posttest design, carried out at MAN 1 Aceh Barat. The sample selection used purposive sampling technique. The study population was class XI-IPA for the 2019/2020 school year and the samples were class XI-IPA2 (experimental group) and XI-IPA6 (control group). Data collection was carried out by giving a pretest and posttest to determine the increase in critical thinking skills. The results showed that the experimental group had an increase in the critical thinking component focusing on indicator questions with an average $\mathrm{N}$-gain percentage of $74.58 \%$ in the high category, while other critical thinking components experienced an increase in the moderate category. Based on the $t$ test, the posttest value of the experimental and control groups has a significant difference with $t_{\text {count }} 2.107>t_{\text {table }}$ 2.093. This difference is influenced by the search, solve, create, and share model of the acidbase titration material in the experimental group. Students gave positive responses to learning to search, solve, create, and share with a percentage of $81.7 \%$ with the interested category. So, it is concluded that learning the search, solve, create, and share model can improve students' critical thinking skills on acid-base titration material.
\end{abstract}

Keywords: search; solve; create and share model; critical thinking skills; acid-base titration.

Citation: Arisa, S., Khaldun, I., \& Safrida, S. (2021). The Effect of Search, Solve, Create and Share Learning Models to Improve Students 'Critical Thinking Skills on Acid and Basic Titration Materials. Jurnal Penelitian Pendidikan IPA, 7(2), 191-195. doi:https://doi.org/10.29303/ippipa.v7i2.625

\section{Introduction}

Education has an important role in advancing every nation, through education it can direct students to become qualified human beings who are able to face challenges that always change with the times. Sudarmin, et al. (2019) stated that in the current global era, the ability to think is very important for students to master. Therefore it is necessary to find ways to develop each potential of each student. Through the touch of learning that provides a stimulus to form students to think critically in learning in order to stimulate skills to be developed as capital for them when they start entering the world of work.

Critical thinking is the way a person processes information through analyzing, observing, and evaluating before determining whether they reject or accept information. According to Putri (2017) that critical thinking uses the basis of a thought process to analyze arguments and generate insights into each meaning and interpretation, develop cohesive and logical patterns of reasoning, understand the 
assumptions that underlie each position. Therefore, the ability to think critically is one of the skills that students must have, because through the ability to think critically, it is easier for them to understand concepts and solve problems on their own (Tresnawati, 2017). Critical thinking skills are important to be stimulated through planned learning in the context of 21st century learning, where students are able to express reasons that support the assumptions or conclusions they get (Rosidin, et al. 2019).

In addition, several interviews stated that the low student learning outcomes in the last few years were influenced by many factors, including the method used was not appropriate so that it resulted in reduced student critical thinking. Typical. R., et al. (2018) states that several factors occur in learning activities. These factors include the learning methods used by the teacher, student motivation and readiness, facilities and learning resources. The learning model or approach used by the teacher is expected to direct students to be active and creative, so that learning becomes learnercentered (Nurmayani, 2018).

Chemistry is generally seen by students as a subject with material that is difficult to understand, such as the acid-base titration material. This is because most of the material requires more understanding and reasoning, because most of the concept of acid-base titration is abstract, so it is difficult to describe it in the proper conditions. Based on the acid-base titration indicator provides the right reason for the sudden color change at the end point of the acid-base titration with certain indicators the average value at the school level is 45.45; Regency of 38.84; Province of 37.75; and at the National level it is 46.87, and the indicators analyze questions related to acid-base titration in certain conditions the average value at the Regency level is 34.03, at the Provincial level is 28.18, and at the National level is 36.52 (BNSP, 2019).

The data above provides information that the level of absorption of students in the acid-base titration material is still lacking. This fact illustrates that there are still most students who have not completely understood the concept of acid-base titration at school. Based on the results of interviews and observations at MAN 1 Aceh Barat, it was found that most students tended to be passive when learning chemistry materials and only received material and question exercises from the teacher.

Some students are still less interested in solving the questions they think are difficult and only rely on answers from other friends or wait for explanations from the teacher without trying to find their own solutions to the problems they face.

Based on the findings above, it is necessary to make a strategic change in learning that focuses on critical thinking skills by presenting the learning process in an active, creative and independent manner, namely by choosing the right model. According to Rustam et al, (2017) the ability to think critically in students can be built with a learning model that applies multi-directional communication between students and students and teachers, such a learning model is student centered.

The learning that is meant is by applying the Search, Solve, Create, and Share (SSCS) learning model. Based on the research finding the SSCS learning model can solve the above problems, such as research by Milama et al. (2017) found that the application of the SSCS model can increase students' critical thinking skills.

Satriawan (2017) examined that the use of the SSCS learning model is one of the lessons that can improve student learning achievement. Saregar, et al (2018) found the same thing that the application of SSCS learning to physics material can improve critical thinking skills in the component of solving problems in a timely manner, and students are more active, effective, and creative. According to Rosidah (2017) the learning process will produce changes in knowledge, skills, and attitudes that are reflected in student learning outcomes.

This article is expected to provide additional empirical evidence on how the SSCS learning model affects the improvement of critical thinking skills in high school students, especially in learning acid and alkaline titration material in chemistry subjects in class XI IPA.

\section{Method}

\section{Research Desain}

The research design was the pretest-posttest design group, namely the treatment given to the experimental group while the control group only used conventional methods, then it was seen the increase in critical thinking skills in the treated and untreated groups.

\section{Population and Sample}

The population in this study were all students of class XI MAN 1 Aceh Barat. The sample was selected by using Porpusive Sampling Technique. The samples in this study were class XI-IPA-2 with 20 students as the experimental group and class XI-IPA-6 with 20 students as the control group. The indicators measured in this study were students' critical thinking skills in chemistry subject matter of acid and base titration which was taught using the Search, Solve, Create and Share (SSCS) learning model. 


\section{Research Instruments}

The initial test instrument consisted of 20 items, with multiple answer choices accompanied by reasons. The test is integrated with critical thinking skills and to find out students' understanding of the concept of acidbase titration material. The results of the preliminary test analysis can be used as a comparison value to the value after the learning process takes place by applying the SSCS learning model to the experimental class. These instruments have been validated and tested. Bustami, et al. (2018) argued that the test items were valid and reliable so that they met the criteria for critical thinking skills, and were worthy of being used as a research instrument.

\section{Data Analysis}

This data analysis aims to see the differences in the results of critical thinking skills before and after learning using the SSCS learning model, it is necessary to analyze data using the N-Gain test and hypothesis testing. N-Gain data analysis aims to see the increase between the pretest and posttest values, while to determine whether or not there is a significant difference between the two samples or variables being compared, a hypothesis test is carried out using the $t$ test which is one of the statistical tests. In this experimental research design, the t-test was also used to test the significance of the mean difference. The formula used is $\mathrm{n}$ with number of samples $(\mathrm{N}) \leq$ from 30 according to (Nurgiyantoro et al., 2009: 183), namely:

$$
\mathrm{t}=\frac{\overline{\mathrm{x}}_{1}-\overline{\mathrm{x}}_{2}}{\sqrt{\frac{\mathrm{s}^{2}}{\mathrm{~N}_{1}}+\mathrm{s}^{2}}}
$$

Description:

$\overline{\mathrm{X}}=$ mean

$\mathrm{N}=$ number of samples

$S=$ standard deviation.

\section{Result and Discussion}

The results of research data analysis on 4 components of critical thinking skills, namely 1) focusing on indicator questions, 2) analyzing and evaluating arguments, 3) asking and answering classification questions and challenging questions, 4) considering whether the source is reliable or not (Ennis, 1986).

Table 1. Average values of pretest and posttest in the experimental class and control class

\begin{tabular}{llll}
\hline No & Data analysis & Experiment Class & Control Class \\
\hline 1 & Pretest Average & 41.00 & 47.00 \\
2 & Posttest Average & 76.75 & 70.50 \\
3 & N-Gain & 0.59 & 0.42 \\
\hline
\end{tabular}

Based on Table 1, it proves that there was an increase between the pretest and posttest scores in both the experimental and control groups. This increase can affect the improvement of critical thinking skills in each indicator. This is because the questions that are designed are integrated with indicators of critical thinking skills, Hatari, et al. (2016) explain that the thinking skills of students can develop through thinking exercises through thinking exercises in responding to a problem, and solving problems. Pursitasari, et al (2020) One of the higher-level thinking skills that can be built through learning science is critical thinking.

According to Ramdani, et al. (2020) Students' mastery of the concept of the material being studied affects their critical thinking skills. Herliandry, et al (2018) argue that critical thinking is very important and can determine the success of life, both in solving problems, making decisions and being a supporter in developing knowledge widely.

Table 2. N-Gain Pretest and Posttest Experiment and Control groups

\begin{tabular}{|c|c|c|c|c|c|}
\hline \multirow{2}{*}{ No } & \multirow{2}{*}{$\begin{array}{l}\text { Component } \\
\text { critical thinking skills }\end{array}$} & \multicolumn{4}{|l|}{ N-Gain } \\
\hline & & Experi-ment Class & Category & Kelas Kontrol & Category \\
\hline 1 & Focusing on indicator questions & 74.58 & High & 25.21 & Low \\
\hline 2 & Analyze and evaluate arguments & 47.50 & Medium & 25.17 & Low \\
\hline 3 & $\begin{array}{l}\text { Ask and answer classification questions and } \\
\text { challenging questions }\end{array}$ & 63.33 & Medium & 26.45 & Low \\
\hline 4 & Consider the source can be trusted or not & 67.50 & Medium & 65.83 & Medium \\
\hline
\end{tabular}

Based on Table 2, it provides information that there is an increase in each component of critical thinking skills in the experimental group with high and medium categories, such as the component focusing on indicator questions, there is an increase of $74.58 \%$ with the high category. Whereas in the control group there was a low and moderate increase in one component focusing on indicator questions of $25.21 \%$ with a low category, because the control class only used the lecture method. Nurhidayah and Wahidin (2018) add that the use of the lecture method is one of the factors for the lack of creativity of students when studying. The increase that occurred in the experimental class was caused by the application of the SSCS learning model 
which was equipped with student worksheets. This helps students understand the acid-base titration material. This condition is a stimulus for students to stimulate students' thinking skills.

This finding is in line with the research of Hifni, et al. (2017) said that the increase in critical thinking skills of students occurred after the SSCS learning model was applied in the experimental class, this condition was because students learned independently to solve problems, so that this situation made students familiar with analyze questions, seek answers and provide solutions to these problems. Mulyana, et al (2018) found the same thing by using the SSCS learning model there was an increase in students' critical thinking skills.

The same thing was also found by Haifa, et al. (2017) explaining that there was also the effect of the SSCS learning model on students' critical thinking skills, in general the data analysis provided information on the improvement of the thinking ability test, the prettest average score was 41.66 and the posttest was 82.47 , so that it was obtained $\mathrm{N}$-gain of 0.70 in the medium category.

The research instrument used to determine students' responses to acid-base titration learning with the SSCS model, namely questionnaire sheets designed with positive questions and negative questions. Student response questionnaire sheet. The questionnaire was filled in by 20 students at the end of the meeting in the experimental class. Then the respective percentage responses were calculated. The results of the questionnaire processing showed that the application of the SSCS Model received positive responses from students, where the average percentage of student responses was $81.7 \%$ with the interested category so that it could improve critical thinking skills. These findings are the same as the results of research conducted by Hatari et al. (2016) explained that the application of the SSCS model is one of the models that is suitable or agreed to be applied to the concept of science.

\section{Conclusion}

The use of the SSCS model in acid-base titration material can improve students' critical thinking skills. The highest increase in the component focuses on indicator questions in the experimental class. The response of students to the application of the SSCS model on acid-base titration material received a positive response or was interested in the average percentage of student responses of $81.70 \%$. Fitri, et al (2018) added that the SSCS model is one of the lessons to develop an understanding of mathematical concepts. This activity is one of the steps or syntax in the SSCS model, so that students interact more independently to answer a problem that has been given by the teacher.

\section{Acknowledgment}

I would like to thank the staff of MAN 1 Aceh Barat for providing the place and opportunity for research data collection and also I thank Syiah Kuala University for helping to carry out this research well.

\section{References}

BNSP. (2019). Data UN Tahun Ajaran 2017/2018. Jakarta: Kementerian Pendidikan dan Kebudayaan. [Indonesian]

Bustami, Y., Syafruddin, D., \& Afriani, R. (2018). The Implementation of Contextual Learning to Enhance Biology Students' Critical Thinking Skills. Jurnal Pendidikan IPA Indonesia, 7(4), 451457. doi:https://doi.org/10.15294/jpii.v7i4.11721

Ennis, R. (1986). Critical Thinking.Upper Saddle River, NJ Prentice-Hall

Fatiyah, H. N., Susanti, R., \& Santoso, L. M. (2017). Pengaruh Penerapan Model Pembelajaran Search , Solve, Create and Share terhadap Kemampuan Berpikir Tingkat Tinggi Peserta Didik Kelas XI SMA Unggul Negeri 4 Palembang Pada Pembelajaran Materi Sistem Ekskresi. Prosiding Seminar Nasional Pendidikan IPA 2017, 504 513. [Indonesian]

Fitri, I., Agustin, S., Rahmi, D., \& Fitraini, D. (2018). Pengaruh Penerapan Model Pembelajaran Search Solve Create Share (SSCS) terhadap Pemahaman Konsep Matematis ditinjau dari Pengetahuan Awal Siswa Sekolah Menengah Pertama Negeri 1 Kampar Kiri Tengah. Jurnal Cendekia: Jurnal Pendidikan Matematika, 2, 42-53. https://doi.org/10.31004/cendekia.v2i2.1 [Indonesian]

Hatari, N., Widiyatmoko, A., \& Parmin. (2016). Keefektifan model pembelajaran search, solve, create, and Share (SSCS) terhadap keterampilan berpikir kritis peserta didik. Unnes Science Education Journal, 5(3), 1418-1423.

Herliandry, L., Harjono, A., \& 'Ardhuha, J. (2018). Kemampuan Berpikir Kritis Fisika Peserta Didik Kelas X Dengan Model Brain Based Learning. Jurnal Penelitian Pendidikan IPA, 5(1). doi:https://doi.org/10.29303/jppipa.v5i1.166 [Indonesian]

Hifni, S, C., Agus, S dan Nyoto, S. (2017). Pengembangan buku ajar perubahan lingkungan berbasis Model search, solve, create, share (SSCS) untuk memberdayakan kemampuan berpikir 
kritis. Jurnal Penelitian Pendidikan Biologi, 1(2):79-

87.

doi:

https://doi.org/10.32502/dikbio.v1i2.661

[Indonesian]

Khasani, R., Ridho, S., \& Subali, B. (2019). Identifikasi Kemampuan Berpikir Kritis Siswa SMP Pada Materi Hukum Newton. Jurnal Penelitian Pendidikan IPA, 5(2), 165-169. doi:https://doi.org/10.29303/jppipa.v5i2.192 [Indonesian]

Milama, B., Bahriah, E., \& Mahmudah, A. (2017). The Effect of Search, Solve, Create, And Share (SSCS) Learning Model towards Student's Critical Thinking Skills. Jurnal Penelitian Dan Pembelajaran IPA, 3(2), 112-123. doi:http://dx.doi.org/10.30870/jppi.v3i2.2574.

Muhammad, C., Falah, N., and Windyariani, S. (2018). Improvement of Students' Critical Thinking Skill Through Search, Solve, Create, and Share (SSCS) Learning. Didaktika Biologi, 2(1):25-32.

Mulyana, Y., Priyatno, S., \& Dewi, N. R. (2018). Penerapan Model SSCS untuk Meningkatkan Kemampuan Membuat Model Matematis dan Kerja Sama Siswa. PRISMA, Prosiding Seminar Nasional Matematika, 1, 225-232. Retrieved from https://journal.unnes.ac.id/sju/index.php/pris ma/article/view/19519 [Indonesian]

Nurhidayah, N dan Wahidin. (2018). Penerapan model pembelajaran Search, Solve, Create and Share (SSCS) pada pokok bahasan sistem ekskresi untuk meningkatkan keterampilan berpikir kritis siswa kelas XI di MAN 2 Kuningan. Jurnal Ilmu Alam Indonesia, 10(10):1-15. [Indonesian]

Nurgiyantoro, B., Gunawan dan Marzuki. 2009. Statistik Terapan Untuk Penelitian Ilmu-ilmu Sosial (edisi keempat). Yogyakarta: Gajah Mada University Press. [Indonesian]

Nurmayani, L., Doyan, A., \& verawati, N. (2018). Pengaruh Model Pembelajaran Inkuiri Terbimbing Terhadap Hasil Belajar Fisika Peserta Didik. Jurnal Penelitian Pendidikan IPA, 4(2). doi:https://doi.org/10.29303/jppipa.v4i2.113 [Indonesian]

Pursitasari, I. D., Suhardi, E., Putra, A. P., \& Rachman, I. (2020). Enhancement of student's Critical thinking skill through science context-based inquiry learning. Jurnal Pendidikan IPA Indonesia, 9(1), 97-105.

Ramdani, A., Jufri, A., Jamaluddin, J., \& Setiadi, D. (2020). Kemampuan Berpikir Kritis dan Penguasaan Konsep Dasar IPA Peserta Didik. Jurnal Penelitian Pendidikan IPA, 6(1), 119-124. doi:https://doi.org/10.29303/jppipa.v6i1.388 [Indonesian]
Rosidah, A. (2017). Penerapan model pembelajaran Kooperatif Snowball Throwing untuk meningkatkan hasil belajar siswa pada pembelajaran IPS. Jurnal Cakrawala Pendas, 3(2). doi:http://dx.doi.org/10.31949/jcp.v3i2.593 [Indonesian]

Rosidin, U., Kadaritna, N., \& Hasnunidah, N. (2019). Can Argument-Driven Inquiry Models Have Impact On Critical Thinking Skills For Students With Different personality Types?. Jurnal Cakrawala Pendidikan, 38(3), 511-526. doi:https://doi.org/10.21831/cp.v38i3.24725

Rustam, Ramdani. A., Setijani, P. (2017). Pengaruh model pembelajaran process oriented guided inquiry learning (Pogil) terhadap pemahaman konsep IPA, keterampilan proses sains dan kemampuan berpikir kritis siswa SMP Negeri 3 Pringgabaya Lombok Timur. Jurnal Penelitian Pendidikan IPA, 3(2). doi:https://doi.org/10.29303/jppipa.v3i2.90 [Indonesian]

Saregar, A., Irwandani, İ., Abdurrahman, A., Parmin, P., Septiana, S., Diani, R., \& Sagala, R. (2018). Temperature and Heat Learning Through SSCS Model with Scaffolding: Impact on Students' Critical Thinking Ability. Journal for the Education of Gifted Young Scientists, 6(3), 39-54. Retrieved from

https://dergipark.org.tr/en/pub/jegys/issue/3 9595/453460

Sudarmin, S., Zahro, L., Pujiastuti, S., Asyhar, R., Zaenuri, Z., \& Rosita, A. (2019). The Development of PBL-Based Worksheets Integrated with Green Chemistry and Ethnoscience to Improve Students' Thinking Skills. Jurnal Pendidikan IPA Indonesia, 8(4), 492499. doi:https://doi.org/10.15294/jpii.v8i4.17546

Tresnawati., Wahyu, H., \& Euis, E.R. (2017). Kemampuan berpikir kritis matematis dan kepercayaan diri siswa SMA. Journal of Research in Mathematics Learning and Education, 2(2): 116122. [Indonesian] 